Harvard Historical Studies - I44

Published under the auspices

of the Department of History

from the income of the

Paul Revere Frothingham Bequest

Robert Louis Stroock Fund

Henry Warren Torrey Fund 

David Paull Nickles

\section{UNDER THE WIRE}

How the Telegraph Changed Diplomacy

Harvard University Press

Cambridge, Massachusetts, \& London, England 2003 
Copyright (C) 2003 by the President and Fellows of Harvard College All rights reserved

Printed in the United States of America

\section{Library of Congress Cataloging-in-Publication Data}

Nickles, David Paull, ig66-

Under the wire : how the telegraph changed diplomacy / David Paull Nickles. p. cm. - (Harvard historical studies ; v. I44)

Includes bibliographical references and index.

ISBN o-674-o 1035-3 (alk. paper)

I. Telegraph-History. 2. Diplomacy-History. 3. Diplomats-History.

4. Negotiation-History. I. Title. II. Series.

$\mathrm{HE}_{7} 6_{3} \mathrm{I} \cdot \mathrm{N}_{5} \mathrm{I} 62003$

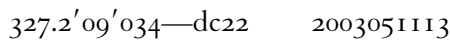

